\title{
Effects of Melatonin on Some Antioxidant Enzymes in Streptozotocin-induced Diabetic Rats
}

\author{
Deniz Uluışık1 ${ }^{1}$, Ercan Keskin ${ }^{1}$, Durmuş Hatipoğlu ${ }^{1}$ \\ ${ }^{1}$ Medicine, University of Selcuk, , Faculty of Veterinary, Department of Physiology, Konya, Turkey \\ Address Correspondence to D, Uluışık, e-mail: denizfedai@selcuk.edu.tr
}

\begin{abstract}
In this study, it was aimed to determine the effects of melatonin application in experimentally induced diabetes. For this purpose, thirty two adult male Wistar Albino rats were used. Animals in control group were not any treatment. Melatonin group animals received $50 \mathrm{mg} / \mathrm{kg}$ melatonin intraperitoneally in daily for eight weeks. Diabetes was induced by subcutaneous injections of streptozotocin at dose of $40 \mathrm{mg} / \mathrm{kg}$ for two days as a single dose per day in diabetes group animals. Animals in Diabetes+Melatonin group were made diabetic by streptozotocin in the same way and then these animals received $50 \mathrm{mg} / \mathrm{kg}$ melatonin intraperitoneally in daily for eight weeks. In blood samples taken from all animals, insulin, glucose, HbA1c, MDA, GSH, SOD were determined. The insulin level in diabetes group was lower than control group, while blood glucose level was higher $(\mathrm{p}<0.05)$. Melatonin treatment to diabetic animals resulted in significantly differences in these parameters compared to diabetes group $(\mathrm{p}<0.05)$. HbA1c in diabetes group was higher than control group $(\mathrm{p}<0.05)$. Melatonin application to diabetic animals significantly decreased HbA1c compared to diabetes group $(\mathrm{p}<0.05)$. In diabetes group, GSH and SOD levels were found to be lower than control group, whereas MDA level were high $(\mathrm{p}<0.05)$. The changes in GSH and SOD levels with melatonin application to diabetic animals were not important compared to diabetes group, while MDA level was significantly reduced $(\mathrm{p}<0.05)$. As a result, we concluded that the melatonin treatment to experimentally induced diabetic rats obviously improved the some negative changes in metabolic parameters resulting from diabetes.
\end{abstract}

Key words: Diabetes, melatonin, antioxidant, $\mathrm{HbA1c}$, rats.

\section{INTRODUCTION}

Today, Diabetes is a disease characterized by hyperglycemia resulting from insulin resistance or insulin insufficiency. Various disorders develop in carbohydrate, fat and protein metabolism as a result of hyperglycemia in diabetes $(30,33)$. The prevalence of this disease, which can be seen at all ages, continues to grow and to become a major health problem worldwide (33). Although the etiology of the disease has not been fully established, autoimmunity, nutritional disorders, obesity, genetic predisposition, viral infection and environmental factors are shown as the cause of diabetes $(19,25,37,50,53)$. There are many complications affecting vascular system, kidney, retina, lens, peripheral nerves and skin in diabetes (30). The increased oxidative stress is one of the most effective factors in the development and progression of diabetes complications $(5,6,10)$. Disorders in diabetes are usually accompanied by increased production of free radicals $(5,6,12,62)$ or deteriorated antioxidant defense systems $(18,32,52)$.
The mechanisms of increased oxidative stress associated with complications of diabetes are partially known. These mechanisms are the activation of transcription factors, advanced glycated end products (AGE) and protein kinase $C$ (PKC) activation caused by hyperglycemia (30).

In addition to the reduction of plasma/serum total antioxidant capacity and free radical scavenging activity in diabetes, it is also reported that levels of specific antioxidants such as ascorbic acid and vitamin $E$ have been reduced $(1,4,11,31)$. Antioxidant enzyme activities (catalase, superoxide dismutase and glutathione peroxidase) have been reported to decrease in diabetes $(4,34,57)$. It has been suggested that there are decreased of vascular antioxidant defense and also deficiency endothelial NO synthesis in patients with type 2 diabetes (23, 28). It has been determined significant reductions in tissue antioxidant enzyme activities [superoxide dismutase (SOD) and catalase (CAT)] in streptozotocin-induced diabetic rats (20). It is suggested that individuals with high levels of serum 
antioxidant capacity (especially those with high levels of tocopherol) have lower development risk of type 2 diabetes (47). There are also studies reporting that there is no significant difference between diabetics and healthy controls in terms of antioxidant status $(16,42,58)$.

In addition to insulin and other medical applications to prevent diabetes and its complications, alternative strategies should be developed in order to increase the life expectancy and quality of patients (30). Melatonin (N-acetyl-5methoxy-tryptamine), the main secretory product of the pineal gland, has important roles in the regulation of reproduction and retinal functions in both circadian rhythm and seasonal rhythm in mammals $(7,9)$. Melatonin has been noted to show antioxidant activity in cell membrane, mitochondria and nuclei in the study conducted as in vivo and in vitro (45). It has been stated that melatonin and its metabolites exhibit redox properties in the presence of electron rich molecules that act as electron donors $(3,56)$. Assessments of the effects of melatonin on glucose metabolism in diabetes have recently aroused great interest (13). It has been reported that long-term administration of melatonin to diabetic rats reduces hyperinsulinemia and hyperlipidemia and improves the rate of changing polyunsaturated fatty acids in serum and tissues (36). It has been claimed that melatonin affects diabetes and diabetes-related metabolic disorders by protection against reactive oxygen species and regulating insulin secretion, as pancreatic $\beta$-cells have low antioxidant capacity and are therefore susceptible to oxidative stress (15). It was reported that the melatonin directly affected insulin secretion by its receptors (MT1 and MT2) found in pancreatic islet cells $(15,21,40,41)$.

This study was planned to determine the effects of melatonin on antioxidant enzymes in streptozotocin-induced diabetic rats.

\section{MATERIAL AND METHOD}

Thirty two adult male Wistar Albino rats were used in the study. Properly living conditions (heat, humidity and light) for rats were provided during the study period. The animals were divided into four groups. Animals in all groups were fed ad libitum with standard rat feed for 8 weeks. The Ethical Committee of Selcuk University Experimental Medicine Research and Application Center approved the study protocol (Report no. 2017-15).

\section{Group I (K) (n=6): No application was made.}

Group II (M) (n=6): $50 \mathrm{mg} / \mathrm{kg}$ melatonin (Sigma-Aldrich, St. Louis, MO, USA) was intraperitoneally administered daily for 8 weeks.

Group III (D) (n=9): Diabetes was induced by administering $40 \mathrm{mg} / \mathrm{kg}$ streptozotocin (SigmaAldrich, St. Louis, MO, USA) in a single dose subcutaneous in $0.1 \mathrm{M}$ citrate buffer $(\mathrm{pH} 4.5)$ for the first two days of the study.

Group IV (DM) ( $\mathbf{n = 1 0 ) : ~ D i a b e t e s ~ w a s ~ i n d u c e d ~}$ by administering $40 \mathrm{mg} / \mathrm{kg}$ streptozotocin (SigmaAldrich, St. Louis, MO, USA) in a single dose subcutaneous in $0.1 \mathrm{M}$ citrate buffer $(\mathrm{pH} 4.5)$ for the first two days of the study and then rats with diabetes were given $50 \mathrm{mg} / \mathrm{kg}$ melatonin intraperitoneally every day for 8 weeks.

Diabetic rats were given orally $5 \%$ dextrose solution 6 hours after streptozotocin application to prevent hypoglycemia for 3 days. One week after streptozotocin injection, diabetes formation (group $\mathrm{D}$ and $\mathrm{DM}$ ) was checked by measuring plasma glucose levels with glycometer (PlusMED Accuro, Taiwan). Rats which have $250 \mathrm{mg} / \mathrm{dl}$ or high blood glucose levels were included in the diabetic groups. One animal from the diabetes group died due to hypoglycemia during the study. At the end of 8th weeks, blood samples was collected from animals in all groups. MDA, GSH and SOD level were determined with ELISA (Biotek ELx800, Biotek Instrumentations, Inc, Winooski, VT, USA) using sandwich enzyme-linked immunosorbent method via commercial kits (Elabscience), while Insülin, Glikoz and HbA1c levels were determined the Abbott C8200 autoanalyzer using Abbott kits.

The data obtained from the study were analyzed by one-way ANOVA (SPSS 19). Differences among the groups were determined by Duncan's multiple range test. Differences were considered significant at $\mathrm{p}<0.05$.

\section{CONCLUSION AND EVALUATION}

\section{Result}

In the study, the changes in insulin, glucose and $\mathrm{HbA1c}$ levels with melatonin treatments to diabetic rats were presented in Table 1 and its effects on oxidative status markers are given in Table 2.

In the study, insulin level significantly decreased and blood glucose level significantly increased in the diabetes group compared to the control group (Table 1, $\mathrm{p}<0.05$ ). The application of 
melatonin to diabetic rats caused significant changes in these parameters compared to diabetes group (Table 1, $\mathrm{p}<0.05)$. In the study, HbA1c levels in diabetic rats significantly increased compared to the control group (Table 1, p<0.05), while HbA1c level was significantly decreased with melatonin application to diabetic rats compared to the control group (Table 1, p<0.05). GSH and SOD levels were significantly lower in experimental diabetic rats compared to the control group (Table 2, $\mathrm{p}<0.05$ ). MDA, a lipid peroxidation product, increased significantly compared to the control group (Table 2, $\mathrm{p}<0.05)$. The melatonin application to diabetic rats significantly decreased MDA level compared to diabetes group (Table 2, $\mathrm{p}<0.05$ ).

\section{Discussion}

Diabetes is a chronic metabolic disease characterized by hyperglycemia or insufficiency of insulin secretion $(6,48)$. This disease brings with it multifunctional insufficiencies including many tissue and organ disorders due to long-term hyperglycemia (6, 22, 29, 48, 60). Antioxidant applications against diabetes complications are considered as an option in preventing various tissue damage and metabolic disorders (8). Melatonin, which is mainly produced in the pineal gland and released from many tissues including the gastrointestinal system, is an interesting hormone in recent studies due to its antioxidant effects $(49,59)$. Melatonin regulating circadian and seasonal rhythm manages reproduction and retinal function in mammals through its many membrane receptors (7, 9). Further, melatonin and its metabolites show redox properties in the presence of electron-rich systems in the base of cell energy function $(3,54)$.

The blood glucose level exhibits circadian rhythm like melatonin. Evaluation of the relationships between glucose metabolism and melatonin has been considered important in respect of diabetes $(13,54)$. In the study, experimental diabetes led to decrement in insulin level and increment in blood glucose level compared to the control group in the diabetes group (Table 1, $\mathrm{p}<0.05)$. The application of melatonin to diabetic rats caused significant improvement in both parameters compared to diabetes group (Table 1, p<0.05). Melatonin possess membrane receptors called MT1 and MT2. It has been reported to regulate secretion of glucagon from $\alpha$-cells and secretion of insulin from $\beta$-cells via these membrane receptors $(21,24$, 39). Activation of MT1 and MT2 receptors has been reported to suppress cyclic adenosine monophosphate (cAMP) or cyclic guanosine monophosphate (cGMP) secondary messenger systems, which reduce insulin secretion and therefore lead to an increase in blood glucose level $(27,51,55)$. Diabetes-induced hyperglycemia causes glycation of proteins $(35,38,54)$. One of the most important results of protein glycation is the increase in the amount of $\mathrm{HbA1c}$, which is called oxidized hemoglobin. In parallel with the above information, $\mathrm{HbA1c}$ level in diabetes group significantly increased compared to the control group (Table 1, $\mathrm{p}<0.05)$. With melatonin administration to diabetic rats, it has been shown statistically significant decrease in $\mathrm{HbA1c}$ level compared to the diabetes group (Table $1, \mathrm{p}<0.05$ ).

GSH and SOD levels in experimental diabetic rats were significantly lower than the control group's level (Table 2, p<0.05). MDA, a lipid peroxidation product, significantly increased compared to the control group (Table 2, $\mathrm{p}<0.05$ ). The changes determined in MDA, GSH and SOD levels support the findings of increased oxidative stress in diabetes as expected $(2,22,59)$. Although it was determined a little increase in the levels of GSH and SOD, there was no significantly changes in these enzymes levels with melatonin application to diabetic animals. The application of melatonin to diabetic animals showed a significant decrease in MDA level compared to diabetes group (Table 2, $\mathrm{p}<0.05)$. In the study, significant changes in MDA and $\mathrm{HbA} 1 \mathrm{c}$ levels as a result of melatonin administration to diabetic animals support the results of various investigators in diabetic rats by melatonin application $(2,22,26)$.

The positive effects of melatonin on total antioxidant capacity and various antioxidant enzymes are based on the strong scavenger of hydroxyl and peroxyl radicals and the regulation of the activities of antioxidant enzymes (43). The reducing effect of melatonin on lipid peroxidation has been attributed to the membrane protective effect by reducing free radicals $(46,61)$. The decrement in NO levels with its scavenging activity of melatonin is regarded as its another antioxidative property in diabetes (54). The effects of melatonin on insulin secretion might be explained with protection of $\beta$-cell integrity or prevention of damage, while its effect on glucose level is explained by increased insulin level and increased glucose transport to muscle. It is reported that melatonin activates the phosphoinositide-3-kinase pathway related to 
glucose transport to muscles. This effect is considered to be a positive effect of melatonin on insulin-independent glucose homeostasis $(17,38)$. In the presence of melatonin in cell cultures, it is reported that SOD mRNA expression is increased, whereas the administration of melatonin to diabetic rats strongly increased GSH-Px and SOD enzyme activities (2, 14, 22, 44, 49). Although the positive effects of melatonin on enzymes such as GSH and SOD are based on strong free radical scavenging properties, the reason for the limited effects of melatonin on these enzymes in this study is due to the dose of melatonin administered in the study.

\section{Conclusion}

Based on the findings obtained in the study, it was concluded that melatonin administration significantly improved the impaired metabolic parameters on rats with streptozotocin induced experimental diabetes. Nevertheless, further studies are needed to be conducted with different dose and duration.

\section{Acknowledgment}

This study was supported by Selçuk University Scientific Research Projects Coordination Unit (Proje No: 17401132).

\section{REFERENCES}

1. Aguirre F, Martin I, Grinspon D, Ruiz M, Hager A, de Paoli T, Ihlo J, Farach HA, Poole CP. Oxidative damage, plasma antioxidant capacity and glucemic control in elderly NIDDM patients-Possible implications for diabetic atherosclerosis. Free Radical Biology and Medicine, 1998; 24(4): 580-585.

2. Aksoy N, Vural H, Sabuncu T, Aksoy S. Effects of melatonin on oxidative-antioxidative status of tissues in streptozotocininduced diabetic rats. Cell Biochemistry and Function, 2003; 21(2): 121-125.

3. Allegra M, Reiter RJ, Tan DX, Gentile C, Tesoriere L, Livrea MA. The chemistry of melatonin's interaction with reactive species. Journal of Pineal Research, 2003; 34(1): 1-10.

4. Ashour M, Salem S, Hassaneen H, El-Gadban H, Elwan N, Awad A, Basu TK. Antioxidant status and insulin-dependent diabetes mellitus (IDDM). Journal of Clinical Biochemistry and Nutrition, 1999; 26(2): 99-107.

5. A Baynes JW. Role of oxidative stress in development of complications in diabetes. Diabetes, 1991; 40(4): 405-412.

6. Baynes JW, Thorpe SR. Role of oxidative stress in diabetic complications: A new perspective on an old paradigm. Diabetes, 1999; 48(1): 1-9.

7. Becker-Andre M, Wiesenberg I, Schaeren-Wiemers N, Andre E, Missbach M, Saurat JH, Carlberg C. Pineal gland hormone melatonin binds and activates an orphan of nucleur receptor superfamily. Journal of Biological Chemistry, 1994; 269(46): 28531-28534.

8. Bojunga J, Dresar-Mayert B, Usadel KH, Kusterer K, Zeuzem $S$. Antioxidative treatment reverses imbalances of nitric oxide synthase isoform expression and attenuates tissue-cGMP activation in diabetic rats. Biochemical and Biophysical Research Communications, 2004; 316(3): 771-780.

9. Brzezinski A. Melatonin in humans. New England Journal of Medicine, 1997; 336(3): 186-195.

10. Ceriello A. Oxidative stress and glycemic regulation. Metabolism, 2000; 49(2): 27-29.

11. Ceriello A, Bortolotti N, Crescentini A, Motz E, Lizzio S, Russo A, Ezsol Z, Tonutti L, Taboga C. Antioxidant defences are reduced during the oral glucose tolerance test in normal and non-insulin-dependent diabetic subjects. European Journal of Clinical Investigation, 1998; 28: 329-333

12. Chang KC, Chung SY, Chong WS, Suh JS, Kim SH, Noh HK, Seong BW, Ko HJ, Chun KW. Possible superoxide radicalinduced alteration of vascular reactivity in aortas from streptozotocin-treated rats. Journal of Pharmacology and Experimental Therapeutics, 1993; 266(2): 992-1000.

13. Derlacz RA, Poplawski P, Napierala M, Jagielski AK, Bryla J. Melatonin-induced modulation of glucose metabolism in primary cultures of rabbit kidney-cortex tubules. Journal of Pineal Research, 2005; 38(3): 164-169.

14. Donder E, Baydas G, Sokmen S, Ercel E, Yalniz M, Dogan H, Bahçeoğlu IH. Investigation of antioxidant and glucometabolic effects of melatonin in experimental diabetes mellitus. Biomedical Research, 1999; 10(2): 127-32.

15. Espino J, Pariente JA, Rodríguez AB. Role of melatonin on diabetes-related metabolic disorders. World Journal of Diabetes, 2011; 2(6): 82-91.

16. Feillet $\mathrm{C}$, Roche $\mathrm{B}$, Tauveron I, Bayle D, Rock E, Borel $\mathrm{P}$, Rayssiguier Y, Thieblot P, Mazur A. Susceptibility to oxidation and physicochemical properties of LDL in insulindependent diabetics. Atherosclerosis, 1998; 136: 405-407.

17. Ha E, Yim SV, Chung JH, Yoon KS, Kang I, Cho YH, Baik $\mathrm{HH}$. Melatonin stimulates glucose transport via insulin receptor substrate-1/phosphatidylinositol 3-kinase pathway in $\mathrm{C} 2 \mathrm{C} 12$ murine skeletal muscle cells. Journal of Pineal Research, 2006; 41(1): 67-72.

18. Halliwell B, Gutteridge JM. Role of free radicals and catalytic metal ions in human disease: An overview. Methods in Enzymology, 1990; 186: 1-85.

19. Kataoka S, Satoh J, Fujiya H, Toyota T, Suzuki R, Itoh $\mathrm{K}$, Kumagai K. Immunologic aspects of the nonobese diabetic (NOD) mouse. Abnormalities of cellular immunity. Diabetes, 1983; 32(3): 247-253.

20. Kedziora-Kornatowska KZ, Luciak M, Paszkowski J. Lipid peroxidation and activities of antioxidant enzymes in the diabetic kidney: effect of treatment with angiotensin convertase inhibitors. IUBMB Life, 2000; 49(4): 303-307.

21. Kemp DM, Ubeda M, Habener JF. Identification and functional characterization of melatonin Mel 1a receptors in pancreatic beta cells: potential role in incretin-mediated cell function by sensitization of cAMP signaling. Molecular and Cellular Endocrinology, 2002; 191(2): 157-166.

22. Klepac N, Rudeš Z, Klepac R. Effects of melatonin on plasma oxidative stress in rats with streptozotocin induced diabetes. Biomedicine and Pharmacotherapy, 2005; 60(1): 32-35.

23. Laight DW, Carrier MJ, Anggard EE. Antioxidants, diabetes and endothelial dysfunction. Cardiovascular Research, 2000; 47: 457-464.

24. Legros C, Devavry S, Caignard S, Tessier C, Delagrange P, Ouvry C, Boutin JA, Nosjean O. Melatonin MT(1) and MT(2) receptors display different molecular pharmacologies only in the G-protein coupled state. British Journal of Pharmacology, 2014; 171(1): 186-201.

25. Like AA, Rossini AA, Guberski DL, Appel MC, Williams RM. Spontaneous diabetes mellitus: Reversal and prevention in 
the $\mathrm{BB} / \mathrm{W}$ rat with antiserum to rat lymphocytes. Science, 1979; 206(4425): 1421-1423.

26. Lo CC, Lin SH, Chang JS, Chien YW. Effects of melatonin on glucose homeostasis, antioxidant ability, and adipokine secretion in ICR mice with NA/STZ-induced hyperglycemia. Nutrients, 2017; 9(11): 1187.

27. MacKenzie RS, Melan MA, Passey DK, Witt-Enderby PA. Dual coupling of MT(1) and MT(2) melatonin receptors to cyclic AMP and phosphoinositide signal transduction cascades and their regulation following melatonin exposure. Biochemical Pharmacology, 2002; 63(4): 587-595.

28. Makimattila S, Liu ML, Vakkilainen J, Schlenzka A, Lahdenperä S, Syvänne $M$, Mäntysaari $M$, Summanen $P$, Bergholm R, Taskinen MR, Yki-Järvinen H. Impaired endothelium-dependent vasodilation in type 2 diabetes. Relation to LDL size, oxidized LDL, and antioxidants. Diabetes Care, 1999; 22(6): 973-981.

29. Malaisse WJ. Alloxan toxicity to pancreatic B-cells. A new hypothesis. Biochemical Pharmacology, 1982; 31(22): 35273534.

30. Maritim AC, Sanders RA, Watkins JB. Diabetes, oxidative stress, and antioxidants: a review. Journal of Biochemical and Molecular Toxicology, 2003; 17(1): 24-38.

31. Maxwell SRJ, Thomason H, Sandler D, LeGuen C, Baxter MA, Thorpe GHG, Jones AF, Barnett AH. Poor glycaemic control is associated with reduced serum free radical scavenging (antioxidant) activity in Non-Insulin-Dependent Diabetes Mellitus. Annals of Clinical Biochemistry, 1997; 34(6): 638-644.

32. McLennan SV, Heffernan S, Wright L, Rae C, Fisher E, Yue DK, Turtle JR. Changes in hepatic glutathione metabolism in diabetes. Diabetes, 1991; 40(3): 344-348.

33. Mohammed A, Adelaiye AB, Bakari AG, Mabrouk MA. Antidiabetic and some haematological effects of ethylacetate and n-butanol fractions of Ganoderma lucidum aqueous extract in alloxan-induced diabetic wistar rats. International Journal of Medicine and Medical Sciences, 2009; 1(12): 530-535.

34. Mohan IK, Das UN. Oxidant stress, antioxidants and nitric oxide in non-insulin dependent diabetes mellitus. Medical Science Research, 1997; 25: 55-57.

35. Montilla PL, Vargas JF, Tlinez IF, Muñoz de Agueda MC, Valdelvira ME, Cabrera ES. Oxidative stress in diabetic rats induced by streptozotocin: Protective effects of melatonin. Journal of Pineal Research, 1998; 25(2): 94-100.

36. Nishida S. Metabolic effects of melatonin on oxidative stress and diabetes mellitus. Endocrine, 2005; 27: 131-136.

37. Paik SG, Blue ML, Fleischer N, Shin S. Diabetes susceptibility of $\mathrm{BALB} / \mathrm{cBOM}$ mice treated with streptozotocin. Inhibition by lethal irradiation and restoration by splenic lymphocytes. Diabetes, 1982; 31(9): 808-815.

38. Peschke E. Melatonin, endocrine pancreas and diabetes. Journal of Pineal Research, 2008; 44(1): 26-40.

39. Peschke E, Bahr I, Mühlbauer E. Melatonin and pancreatic islets: interrelationships between melatonin, insulin and glucagon. International Journal of Molecular Sciences, 2013; 14(4): 6981-7015.

40. Peschke E, Fauteck JD, Musshoff U, Schmidt F, Beckmann A, Peschke D. Evidence for a melatonin receptor within pancreatic islets of neonate rats: functional, autoradiographic, and molecular investigations. Journal of Pineal Research, 2000; 28: 156-164.

41. Picinato MC, Haber EP, Cipolla-Neto J, Curi R, de Oliveira Carvalho CR, Carpinelli AR. Melatonin inhibits insulin secretion and decreases PKA levels without interfering with glucose metabolism in rat pancreatic islets. Journal of Pineal Research, 2002; 33: 156-160.
42. Rahimi R, Nikfar S, Larijani B, Abdollahi M. A review on the role of antioxidants in the management of diabetes and its complications. Biomedicine and Pharmacotherapy, 2005; 59: 365-373.

43. Reiter R, Tang L, Garcia JJ, Munoz-Hoyos A. Pharmacological actions of melatonin in oxygen radical pathophysiology. Life Sciences, 1997; 60(25): 2255-2271.

44. Reiter RJ. Oxidative processes and antioxidative defense mechanisms in the aging brain. FASEB Journal, 1995; 9(7): 526-533.

45. Reiter RJ. Melatonin: lowering the high price of free radicals. News in Physiological Sciences, 2000; 15: 246-250.

46. Reiter RJ, Tan DX, Manchester LC, Qi W. Biochemical reactivity of melatonin with reactive oxygen and nitrogen species: a review of the evidence. Cell Biochemistry and Biophysics, 2001; 34(2): 237-256.

47. Reunanen A, Knekt P, Aaran RK, Aromaa A. Serum antioxidants and risk of non-insulin dependent diabetes mellitus. European Journal of Clinical Nutrition, 1998; 52: 8993.

48. Robertson RP. Chronic oxidative stress: a central mechanism for glucose toxicity in pancreatic islet beta cell in diabetes. Journal of Biological Chemistry, 2004; 279(41): 42351-42354.

49. Rodriguez C, Mayo JC, Sainz RM, Antolin I, Herrera F, Martin V, Reiter RJ. Regulation of antioxidant enzymes: a significant role for melatonin. Journal of Pineal Research, 2004; 36(1): 1-9.

50. Sandler S, Andersson AK, Barbu A, Hellerstrom C, Holstad M, Karlsson E, Sandberg JO, Strandell E, Saldeen J, Sternesjo J, Tillmar L, Eizirik DL, Flodström M, Welsh N. Novel experimental strategies to prevent the development of type 1 diabetes mellitus. Upsala Journal of Medical Sciences, 2000; 105(2): 17-34.

51. Sartori C, Dessen P, Mathieu C, Monney A, Bloch J, Nicod P, Scherrer U, Duplain H. Melatonin improves glucose homeostasis and endothelial vascular function in high-fat diet-fed insulin-resistant mice. Endocrinology, 2009; 150(12): 5311-5317.

52. Saxena AK, Srivastava P, Kale RK, Baquer NZ. Impaired antioxidant status in diabetic rat liver. Effect of vanadate. Biochemical Pharmacology, 1993; 45(3): 539-542.

53. Shewade Y, Tirth S, Bhonde RR. Pancreatic islet-cell viability, functionality and oxidative status remain unaffected at pharmacological concentrations of commonly used antibiotics in vitro. Journal of Biosciences, 2001; 26(3): 349-355.

54. Sudnikovich EJ, Maksimchik YZ, Zabrodskaya SV, Kubyshin VL, Lapshina EA, Bryszewska M, Reiter RJ, Zavodnik IB. Melatonin attenuates metabolic disorders due to streptozotocin-induced diabetes in rats. European Journal of Pharmacology, 2007; 569(3): 180-187.

55. Sun H, Wang X, Chen J, Song K, Gusdon AM, Li L, Bu L, Qu S. Melatonin improves non-alcoholic fatty liver disease via MAPK-JNK/P38 signaling in high-fat-diet-induced obese mice. Lipids in Health and Diseases, 2016; 15: 202.

56. Tan DX, Manchester LC, Terron MP, Flores LJ, Reiter RJ. One molecule, many derivatives: a never-ending interaction of melatonin with reactive oxygen and nitrogen species?. Journal of Pineal Research, 2007; 42: 28-42.

57. Tüzün S, Girgin FK, Sözmen EY, Menteş G, Ersöz B. Antioxidant status in experimental type 2 diabetes mellitus: effects of glibenclamide and glipizide on various rat tissues. Experimental and Toxicologic Pathology, 1999; 51(4-5): 436441.

58. Willems D, Dorchy H, Dufrasne D. Serum antioxidant status and oxidized LDL in well-controlled young type 1 diabetic 
patients with and without subclinical complications. Atherosclerosis, 1998; 137: 61-64.

59. Winiarska K, Fraczyk T, Malinska D, Drozak J, Bryla J. Melatonin attenuates diabetes-induced oxidative stress in rabbits. Journal of Pineal Research, 2006; 40(2): 168-176.

60. Wolf SP, Dean RT. Glucose autoxidation and protein modification. The potential role of "autoxidative glycosylation" in diabetes. Biochemical Journal, 1987; 245(1): 243-250.

61. Yavuz O, Cam M, Bukan N, Guven A, Silan F. Protective effect of melatonin on $\beta$-cell damage in streptozotocininduced diabetes in rats. Acta Histochemica, 2003; 105(3): 261266.

62. Young IS, Tate S, Lightbody JH, McMaster D, Trimble ER. The effects of desferrioxamine and ascorbate on oxidative stress in the streptozotocin diabetic rat. Free Radical Biology and Medicine, 1995; 18(5): 833-840. 